\title{
Apor, Balázs. 2017. The Invisible Shining: The Cult of Mátyás Rákosi in Stalinist Hungary, 1945-1956. Budapest: Central European University Press, 388 pp.
}

\author{
Reviewed by David A.J. Reynolds, ${ }^{*}$ Independent Scholar
}

One of the defining moments of Hungarian Stalinism was when, on October 15, 1949, the former Interior Minister László Rajk went to the gallows. And as this most notable communist victim of Mátyás Rákosi's regime awaited his execution, his last words rang out in the prison courtyard: "Long live Stalin! Long live Rákosi!" What can we make of his orthodox and loyal farewell? There is a temptation to regard it as but the stubborn conformity of a true believer. But was it not also the ultimate expression of the Stalinist cult of personality for the victim to thus acknowledge his executioners? This conclusion is one of many reckonings with Hungary's version of the cult of personality that Balázs Apor, of Trinity College Dublin's Centre for European Studies, inspires us to grapple with as he scrupulously unpacks it in The Invisible Shining. We cannot toss aside the cult-however vulgar and leaden-footed it may appear to usas just another clumsy relic of communist hubris. Whatever Rajk believed in that terminal moment, there is a sense in which his gesture, and many other like it, demonstrate the basic success of the organized veneration of Rákosi, particularly between 1949 and 1953.

As Apor extensively illustrates from sources of the period, the Rákosi cult functioned and proliferated, in part, as a mode of discourse. In particular, once the Communist Party (newly the MDP: Magyar Dolgozók Pártja) seized, in 1949, undisputed control of the government, the ritualized manner of honoring the Party leader-modelled and disseminated from the center of power-became a key mechanism for functionaries and citizens alike to acknowledge and defer to the new order. But as soon as excessive praise of Rákosi became standard practice, it also began to lose the meaning for which it initially reached. Eventually "the language of the cult, when used as a mode of communication between the authorities and its citizens," Apor concludes, "became repetitive, and, like the overall cult propaganda, it was superficial, monotonous, and dull" (259). The bloodless emptiness of the Rákosi cult was ultimately deepened by its resolutely abstract substance. As was also the case for the Stalin cult, which served as model and parent of Hungary's version, there was little to no connection between the Rákosi portrayed by cult propaganda and the real man behind it.

It was not merely that the Rákosi of the cult was inflated by hyperbole, but that he was not portrayed as a conceivable individual; there were no family insights, personal details, or particular traits. Instead, Apor describes, the Rákosi of cult discourse became "the epitome of

*david.reynolds@alej.cz

$($ (c) $)$ EY

ULIS D-Sorke 
officially celebrated, ideal values . . . based not on the leader's individual merits but rather on the highly abstract, impersonal values of the Communist movement" (125). There was, of course, methodical logic to this portrayal rooted in the holistic communist project that the leader cult was designed to serve. Behind the escalating adulation of Rákosi by the Hungarian party and regime, Apor elucidates, was the hope of inculcating "the core values of Communism in society, in accordance with the monumental strategy to remould social identities and create the socialist 'New Man"' (125). As the Red Army's post-war finger on the scales of Eastern and Central Europe enabled communist takeovers across the region, the ensuing leader cults in Hungary and other Soviet-bloc countries were tools in a series of fundamental and interlinked social revolutions.

Therefore, the use of an individual leader as the focus and epitome of communist propaganda, first in the Soviet Union and then across its satellites, was a mitigating concession to the history and psychology of their peoples. It was hoped that the projected image of the great leader could connect people to the abstract and impersonal ideals of communism in a way that mere talk of party and ideology could not. But, in order for a leader cult to serve this goal rather than distract from it, the person of the leader could be neither more nor less than an effective symbol and representative of the party and its cause. As Apor explains, the numerous quasireligious verbal and written declarations to which Hungarians were subjected portraying Rákosi as an extraordinary, infallible leader were intended to create a new emotional connection between the new leader and society that would thus also serve as a legitimizing bond between Hungarians and their regime. To do this, the cult's subject had to personify the Party, the working class, and the nation.

We should note that Apor is careful to avoid employing the term cult of personality. Certainly, this coinage and its widespread use by communist leaders as a vague and selfexculpatory condemnation renders it both loaded and unfit for objective use. But just as importantly, Apor justifiably regards this term as a misnomer. The versions of Stalin and Rákosi projected to millions were by no means personalities, but abstract personas, which is why Apor prefers the more sober label of leader cult for this phenomenon. Apor's corrective of our often too imprecise assessments of Rákosi's cult goes far beyond this, and he is most helpful and pertinent regarding the cult's idiosyncratic elements. Apor is keen to redress the tendency to assume that "the constructed personae of mini-Stalins in the Soviet bloc were merely clones of Stalin's mythical image" (19). The spread of leader cults across communist Europe was not just the production of facsimiles. Rather, Apor's analysis of the specifically Hungarian elements of Rákosi's cult, in connection with the overall communist project of recasting national history, is an invaluable contribution to our understanding of what made this regime distinctive.

However, despite his stress on the national components of the Rákosi cult, Apor concludes that it was still deeply undermined by its enduring and unmistakable reliance on Soviet models and impositions. "In the minds of the population, the country's subordination to the Soviets seems to have overshadowed the national visage of the MDP and its leaders ... and the cult of Rákosi was usually regarded as an essentially Soviet phenomenon" (256). Thus, Apor's analysis makes it clear that the vulnerability of the Rákosi cult was at least partly due to its umbilical connection not only to the Soviet Union in general, but also specifically to the Stalin cult. Tellingly, when this cord was cut, with first the death of Stalin, and then the sullying of Stalin's cult by Khrushchev, the leader cult of Rákosi could not survive. Apor's conclusion that the Rákosi cult "found little fertile ground" (259) in Hungary is amply supported by the author's account of the cult's withering after June 1953, when the Soviet leadership lambasted 
Reynolds, David A.J. “Apor, Balázs. 2017. The Invisible Shining: The Cult of Mátyás Rákosi in Stalinist Hungary, 1945-1956. Budapest: Central European University Press, 388 pp." Hungarian Cultural Studies. e-Journal of the American Hungarian Educators Association, Volume 13 (2020) DOI: 10.5195/ahea.2020.406

Rákosi's cult of personality and other Stalinist elements of the Hungarian regime, leading to that month's appointment of Imre Nagy's as the new Hungarian Prime Minister.

But its total dependence on Soviet support was not the only weakness of the Rákosi cult that Apor dissects. The party had "desperately tried to engender a constant flow of positive emotions toward its leaders" (228), resulting not only in the ritualistic displays of enthusiasm for Rákosi's name, person, and speeches that formed part of the leader cult between 1949 and 1953, but also in the obsessive reporting of these responses in the press. Most revealing of all is Apor's mining of the mood reports produced by the OPO (Országos Propaganda Osztály) ['The State Propaganda Department'], the findings of which suggest that there was a feedback-loop between party functionaries and activists, in which certain cultic performances were expected, induced, and ritually reported with identical formulations, until even internal reports became merely another performance echoing the original artificial public ritual. "The writing of enthusiastic reports about propaganda events was also integrated into the process of imagining consensus," Apor reflects. "Documents noting the enthusiastic reception of the leader were thus ritualized components of the regime's" construction of the "illusion of unity" (188). Therefore, the more the regime strived to achieve the genuine public adulation of Rákosi, the more it incentivized a mere acquiescence with it, until the cult largely consisted of the regime loudly insisting to both itself and the nation that which both knew to be untrue. This phenomenon is underlined by Apor's conclusion that "even as the cult grew after 1949, Rákosi's reputation withered" (186). While Apor's analysis exposes the apparent indifference of most of the population to the leader cult, he also offers examples of clear hostility. On the one hand, Apor, again drawing from the regime's own mood reports, notes that "indifference to politics and the regime's propaganda messages ... was repeatedly observed" (233). But, on the other hand, his investigation also suggests that people were repulsed by element of the cult, and that its ubiquity "caused disapproval, irritation, and hostility in Hungarian society" (256-57).

What then was the connection between the indifference and the hostility of many Hungarians to the leader cult and the regime that pushed it? Apor has established the presence of widespread indifference to the cult, as well as observed the hostility that was particularly evident when the cult first withered and then died. And this suggests an intriguing avenue for further study. Indifference, as Apor himself notes, is hard to pin down: it can indicate genuine disinterest, or be a mask and a symptom of far deeper underlying responses, such as a fundamental moral rejection of communist ideas, that must be repressed or hidden from view. Once we have concluded that the leader cult was mostly adhered to in public and that the people were often indifferent to what they dutifully performed, we must then also ask whether hostility grew from indifference, or whether the indifference of many Hungarians was the consequence of a long-simmering hostility that could not be expressed. In other words, was hostility the central underlying and pervasive response of a majority of Hungarians to the leader cult from 1949 to 1953; and if so, then is this the base phenomenon to which indifference is a mere appendage? This is a fearsomely hard question to answer seventy years later, as Apor's painstaking work to glean what he has from contemporary sources makes clear. But it is a query that his work inspires us to pose, particularly in reference to the religious convictions of post-war Hungarians.

Strangely, since no-one would have known the falsity of the cult's projections more than Rákosi, he was "probably the last person to demonstrate faith in the extraordinary qualities of the MDP leader," Apor notes, "and the last to demonstrate a sincere attachment to the imagery of his cult" (331). All this goes to show the impossibility of gauging and defining sincerity in the human mind; we will never get to the bottom of this phenomenon. But what Apor has concretely 
Reynolds, David A.J. “Apor, Balázs. 2017. The Invisible Shining: The Cult of Mátyás Rákosi in Stalinist Hungary, 1945-1956. Budapest: Central European University Press, 388 pp.” Hungarian Cultural Studies. e-Journal of the American Hungarian Educators Association, Volume 13 (2020) DOI: 10.5195/ahea.2020.406

given us in The Invisible Shining is an invaluable investigation and analysis, assiduously compiled, of how Rákosi's leader cult was constructed and imposed in Hungary. This was a grandiose utopian project served by most mundane and fallible means. Apor's study will be a sturdy platform for anyone subsequently taking up the study of this brief but fateful cult and regime. 